\title{
Reflexivity and medical ethics in social sciences
}

\begin{abstract}
This article proposes to address the research conditions by underlying the question of male homosexuality in Senegal and to show how researcher deals with social and cultural realities in the context of "anthropology at home". It is also a discussing of medical ethics more specifically the consent in social sciences according to my research and my target population. All the data come from my ethnographic work carried out between 2009 and 2013 in Senegal as part of my doctorate thesis in medical anthropology.
\end{abstract}

Keywords: Reflexivity, medical ethics, ethnography, homosexuality, senegal
Volume 2 Issue 3 - 2017

\author{
Ndeye Ndiagna Gning \\ Postdoc in Medical Anthropology and department of Social and \\ Preventive Medicine, CHU Research Center of Quebec-Laval \\ University, University of Laval, Canada
}

Correspondence: Ndeye Ndiagna Gning, Postdoc in Medical Anthropology and department of Social and Preventive Medicine, CHU Research Center of Quebec-Laval University, University of Laval, Canada, Email gnagna.gning@gmail.com

Received: July II, 2017| Published: December 06, 2017

\section{Introduction}

\section{Reflexivity: return on research conditions}

Ethical and methodological issues have been the subject of several volumes. Several reflections, notably on social hierarchies and / or socalled sensitive areas ${ }^{1-7}$ discuss the conditions of obtaining the data, the researcher's status (gender, age, culture, commitment and distancing, etc). While in the West this question of reflexivity is far from new, yet in other contexts the contrast is striking. Indeed, few African expose in their researchers' books their conditions of investigation. And yet, these questions are far from futile. Indeed, as Christian Ghasarian ${ }^{2}$ emphasizes, reflexivity is more necessary than ever to the researcher at the risk of making "conventional" ethnography, or non-reflexive and limited, not to say to the biased, as well so that you are well in the far-off lands than those where the otherness does not jump to the eyes ". To this must be added the question of ethics, which is an important issue in anthropological research and which arises with certain acuity according to the objects of study as well as the methodological choice. Nowadays, the submission of a project to national and international research committees becomes a must for any researcher who deals with a subject related to population health and more specifically in relation to AIDS in the countries of the South in accordance with the charter of ANRS (National Agency for research on AIDS and viral hepatitis). Under these conditions, the beginning of a research, even in the social sciences, depends on the opinion of these committees, which may be to refuse their realization, if they consider that the researcher does not respect an ethics often thought in the Medical field. So, within the framework of my thesis, I had to submit a file to the national research committee of Senegal. However, as others have already pointed out in many respects, the applicability of medical ethics is a problem in social sciences (risks underestimated for participants, limited access to informants, difficulties in signing informed consent, tec.). Starting from these remarks, I return in this analysis on the situations of investigation on the illustrator concretely how to work on homosexuality is not easy. I feel the deontological and methodological difficulties of making the field "at home" on a taboo subject such as homosexuality (in view of the legal and social situation of homosexuality in Senegal) and present the postures I adopted. This question is indeed crucial when the researcher is a woman, Muslim and Senegalese. At the same time, I will discuss the difficulty of respecting anonymity and confidentiality in the face of NGO solicitations and the requirements of the Senegal National Research Ethics Committee. It is a matter of showing ethnographic ethics. It cannot be summed up as a set of rules defined a priori by a committee, but rather as opposed to contextual and pragmatic approach.

\section{The ethnographer, the social expectations and the field}

From a methodological and epistemological point of view all fields presents difficulties. However, it must be recognized that working on homosexuality is not self-evident. As Howard Becker ${ }^{8}$ writes "The moral phenomena involved in any study of deviance are difficult to master. This question is one aspect of a more general problem, that of the researcher's view of what is conventionally held to be evil and the sympathies he feels for a particular category". These constraints arise naturally in the study of any subject, but they are likely to be more acute insofar as the practices of the actors to which the investigation relates are conventionally blamed. These seemed even more complex to me when addressing the issue of homosexuality as I belong to the majority group that largely conveys negative stereotypes about men with multiple sexual identities ${ }^{1}$. In fact, I knowingly decided not to talk about my research to my family (because it does not have the same setback as me) so as not to answer some questions and to better protect my informants. As Fatoumata Ouattara mentioned, "certain family requirements go against the requirements of the investigation". I also must admit that working on homosexuality was not obvious at first. This necessitated a real work of disengagement, a distancing of the prejudices which I carried through my education, my cultural environment. It was in Bordeaux that I began a "disenchantment" enterprise, a break with preconceptions, thus applying to myself the first rule of the sociological method. ${ }^{10}$ This deconstruction of my object of study could not have been done despite my initial good will, without the help of Jean ${ }^{2}$. I used to share with him and other girls (known almost at the same time in our common workplace in

${ }^{1}$ Here, I prefer the periphrasis "men with multiple sexual identities" because the term MSM [Men who have sex with men] or its French equivalent HSH [Men who have sex with men] is a language belonging to a large part of the register mobilized by the associations in Senegal but the individuals met use it only occasionally in their daily life or in specific contexts or with specific interlocutors.

${ }^{2}$ All given names given in this text have been modified. With men with the men met in Senegal this was the subject of a personal choice on their part for the purposes of the investigation 
2009) outings in the restaurant or evenings at one of us sporadic way. However, we both had regular exchanges on certain social networks (MSN, for example, chat software on the net) and by telephone. Jean, a native of Lyon, had settled in Bordeaux since 2008 in a home for young workers. He is 25 , full of life, funny, friendly, a little bit "crazy" (as he likes to say). At the time of our meeting, he had not revealed his homosexuality to his family. For all that, Jean does not resolve to conceal his homosexuality faced with a fear of rejection. Moreover, in the following months, at the end of 2009, Jean will be coming out on a show on France2 (French television). Through the meetings and discussions with Jean, I learned to know him better by listening to him, discussing and exchanging with him about his experience, without moral judgment. I learned to deconstruct my own stereotypes, which allowed me to scientifically base my work. It was from my discussions with Jean that I was led to focus more on the social dimension of the experience of homosexuality (family, social, professional life, difficulties encountered daily, etc.) than the sexual dimension. Other meetings, with homosexual activists at AIDES Gironde, were also useful to me, although they did not have the same importance as my exchanges with Jean. Once in Senegal, this learning was very useful on my field. But, it did not avoid the difficulties encountered when someone makes "anthropology at home" on homosexuality. If, according to Jean Pierre Dozon ${ }^{11}$ there are subjects who allow a certain "ethnographic comfort" in my case it is rather the reverse. My scientific interest in homosexuality has aroused both astonishment and incomprehension.

Mistrust was manifested in the MSM in the fashion of "what did she come to seek?" This mistrust has been further increased by the fact that my informants have had difficulty situating anthropology in relation to professions such as journalism. The mere fact that I was equipped with a recorder was enough to assimilate me to this profession. Some men only told me later in the investigation that I had initially aroused mistrust in them. "Sincerely the first time we saw you we said we should be careful, she must be a journalist!? "If, as reported by Daniel Bertaux, ${ }^{12}$ journalists "have a bad reputation $\ldots,{ }^{12}$ this is particularly true in the Senegalese community of men with multiple sexual identities to whom they have made wrong with their articles and comments. As a reminder, it was through strong political mediation that the controversy over homosexuality took shape in public space. Indeed, since 2008, these men are the subject of considerable attention from the Senegalese media. For several months, they made the front page of the local newspapers (popular and official). They are presented in the media in devaluing and insulting terms such as: "fade, dunk, ${ }^{4}$ homo, or goorjigeen ${ }^{5}$ (goor: man/jigeen: woman, goorjigeen literally means man-woman. This media coverage was accompanied by a series of violence and the arrest of several of these men. The most publicized arrests were those of the five-people arrested by the Criminal Investigations Division in February 2008, following the publication of two men's wedding photos in Petit-Mbao (20km southeast of Dakar) by the magazine Icone (people magazine) following in 2009 by the arrest of nine associations in the residence of

${ }^{3}$ It should be noted that this type of remark came more from non-activists than from associations that used to participate in research.

${ }^{4}$ Dunk means feather, pejorative vernacular term to designate these men.

${ }^{5}$ In the usual sense, this term covers two dimensions: social and sexual. On this last point, the term goorjigeen (literally man-woman) is an exo-designation, a term of stigma, consequently discriminatory for the men concerned. However, though in some respects insulting, defamatory and infamous, the use of the term goorjigeen by these men is thought to be affectionate, marking a shared experience the president of AIDES-Senegal (association of $\mathrm{MSM}^{6}$ ) condemned by the court of Dakar to eight years in prison for "act against nature and association of criminals" before being released in June 2009. ${ }^{13}$ Besides the suspicion, the interest in homosexuality also arouses indignation on the part of the populations and some relatives. This poses the problem of the acceptability of the term homosexuality as an object of study and testifies to the status of homosexuality in Senegalese society. Michael Pollak ${ }^{14}$ already noted in 1982 that "every scientific view of homosexuality is problematic". Me who thought that I had escaped from the misunderstanding that my subject could bring to my family, I now see myself confronted with inquisitive interrogations of certain knowledge. I can quote the words of this Senegalese friend: "I knew you loved complicated subjects, but frankly the very incongruity of homosexuality deserves little attention." He continues: "I hope that you are Muslim and Senegalese you do not endorse such behavior (talking about sexual practices between men). In fact, it was because of my religious affiliation that certain leaders of local NGOs (not MSM) were offended because I was conducting interviews in the middle of Ramadan (holy month, repentance for Muslim believers). One of these addresses thus to me in a joking tone certainly, but critical: "your fast will not be accepted. You're going to talk to them! Me, during the month of Ramadan, I limit my contacts with these MSM". As a member of Senegalese society, I am conscious of such norms and values, or at least I cannot escape them in my home environment. The difficulty of my investigation was therefore to combine respect for the norms of sociability, social, religious and cultural belonging and investigative postures to recapitulate Mamadou Diawara..$^{15}$ Thus, "the whole question is how to ensure that the cultural proximity of the indigenous researcher does not engender a form of ethnographic blindness, an inability to look beyond the rule and evidence?". ${ }^{16}$

\section{Between commitment and distancing, what position to adopt?}

For Michel Agier, ${ }^{1}$ the position of the researcher in this case should not be "neither too far nor too closes while remaining in a position of critical engagement that guarantees his autonomy as a researcher and of citizen ". Taking this recommendation to heart, I juggled throughout the investigation with different postures that were defined by the relationship with the respondents, considering that "the necessary process of objectification of the researcher allows him, by his methodological rigor and reflexivity, to claim to surpass his own subjectivity". ${ }^{17}$ The adoption of an empathetic posture, the suspension of my judgment and the non-moral framework that was mine, was therefore necessary to understand and faithfully reproduce the experiences of the men I met. However, other biases show that the place or the acceptance of the researcher on his field is a continuous work and considers several aspects. As Olivier Leservoisier ${ }^{18}$ notes: "(the presence of the researcher in the field) is not necessarily acquired and the acceptance or not of his presence depends on the place that the society assigns to the latter according to the parameters as different as age, sex, or social status, to mention only the main ones)". I will start with this remark by the author, to reflect on the place of the ethnologist, woman, indigenous on the field of homosexuality.

\section{Constraints and stakes in field practice in senegal}

Right from the start, being a woman and a Senegalese seemed to me to be an obstacle to my integration into the MSM community in Senegal. The refusal of some married men confirmed this fear. This was the case one day in September 2010. While I was doing ${ }^{6}$ As they call themselves within the framework of the fight against AIDS. 
an interview on the beach with Bernard (an associative), I made the acquaintance of Noel. The latter, 32 years old at the time of the investigation, is married and has two children. He is a native of the Dakar but occupies a guard post in Mbour (a tourist site in the city of Thies). His job consists to supervise the house of a French owner in his absence. It is in front of the villa of the latter that is the hut in which Bernard and I settled around noon to hold the interview. The straw hut offers us an appreciable shelter against the very burning sun this time of the day. Ten minutes after we arrived, a man appeared before us. He is of medium height, with a small beard, dressed in shorts and t-shirt, face sweaty (he played football).

Having noticed our presence on the scene, he approached us. Bernard explains that we are here to work and that the hut being unoccupied and far from the bathers present on the beach, we chose to settle there. The attitude of Noel with Bernard (all smiling and warm with respect to him) testified then of their acquaintanceship (what Bernard confirms me). Very quickly, the attention of Noel is now only on me and he proposes to kindly grant him five minutes at the end of my discussion with Bernard. Once he returns to play football with his friends, Bernard tells me: "si sama mbaraan-yi la bokk" (he is one of my casual sexual partners). And he even proposes to speak to him so that he may grant me an interview, which I accept. An appointment is therefore made for the next day. I present myself as agreed upon at the appointed time. However, after "naaga def, mangui fi rek" me because I like him, this surprised me greatly because Bernard had promised to explain to him the object of this appointment. So, as a matter of prudence, I did not discuss with him the subject of my work and after leaving him, I hastened to call Bernard to find out what he had told him. Bernard assured me that Noel was aware of the subject of the exchange I had with him, but that being woman and Noel being "bisexual", he simply did not want to reveal his other sexual identity. Bernard told me that Noel had confided that he was embarrassed to approach this subject with a woman and that he had never done it with his wife. He went on to explain that if I had been a man he would have been more cooperative. I did this experience several times during my investigation. Thus, Alexander opposed the same argument when I asked for his help to meet his sexual partners (married and fathers) with whom he lives in the same neighborhood. "I spoke with them and I told them that you guaranteed them anonymity and confidentiality. But they categorically reject the idea of meeting a woman. You know, they're married men no one suspects their homosexuality. I understand their position "(Telephone discussion with Alexandre, Dakar October 2010). This field experience opens up a perspective on understanding the status of the female ethnographer in the field of male homosexuality in Senegal. The objective of this analysis on the gender of the ethnographer, as Marieké Blondet ${ }^{19}$ points out, is not to "try to minimize the obstacles that a man must face in the field". Indeed, it can be assumed that such an investigation also presents difficulties for a heterosexual and Senegalese man because he risks being assimilated to this marginalized group.

This means that he may be subject to stigma and discrimination just as a researcher who has sex with a person of the same sex..$^{20}$ But, besides the difficulties connected with the object studied which arises for any ethnographer, I would like to emphasize the difficulties specific to the female ethnographer. This dimension is often neglected. As Marieke Blondet ${ }^{19}$ rightly pointed out: "the first steps on the field are always decisive it is from them that access to the data which the ethnographer needs will depend. If this is true for any researcher, it

${ }^{7}$ Greetings in Wolof (national language in Senegal) appears that these first steps are even more subtle to negotiate when it comes to a female ethnographer. The question in particularly of its position and its integration into the community it is studying arises in a lively way ". In other words, if the anthropologist can afford to take an interest in any subject with a scientific significance, in certain situations, there are considerable obstacles before confronting him with the feasibility of his study. In some cases, these biases can be explained by a lack of legitimacy insofar as the researcher does not necessarily share the beliefs, values or practices of the social groups studied, as argued by Patrick Awondo ${ }^{21}$ in his doctoral thesis. Beyond the question of the legitimacy of the researcher to study a group that has sexual realities different from his own, it is question of the sex of the anthropologist on the field of homosexuality. The words that Noel entrusted to Bernard explicit: the embarrassment of approaching this subject with woman so far as he never did it with his spouse. On the other hand, if it were a man it would have been more cooperative" is a good example. Being a woman has limited access to some informants. And in the context of social and cultural proximity, the "sex of the ethnographer" arises in more complex terms. Starting with work schedules (on weekends, but also arriving very late at night), which are difficult to accept for the relatives of a young woman who is single and childless. Similarly, some places (bars, hotels, tourist sites, etc.) prohibited, connoted negatively, where the mere presence of the researcher risks not only shocking, but also can be worth some moral judgments (bad girl, night girl, etc.). So, from time to time, my big sister reminded me when I came home late and told me not to obscure Senegalese`s realities concerning girls who move all the time.

According to her, people can label me as "jigeenu guddi" (literally night girl), in other words, a prostitute. In Senegal, as Gora Mbodj22 recalls, in the Wolof society the woman must have "short steps" (gate tank). This means not going out home too often. If this conduct is expected of the married woman, it is more so for a young single woman, because this is part of the qualities sought when choosing the spouse. In this context of inquiry, the status of woman is also conjugated with autochthony. Conversely, it must be said that anthropology "at home" also has certain advantages. Membership in Senegalese culture has been useful to me as I speak Wolof (local language), so I did not need an interpreter and coming from France and preparing from Bordeaux allowed me to develop a feeling of strangeness towards my own society allowing me to better interrogate him. Also, being a woman helped me in this research, since most men with multiple sexual identities surround themselves with girls called "jéeggu ubbi", (jéeg: a non-virgin woman and / or a married / ubbi ${ }^{8}$ : open), ${ }^{23}$ with whom they have very good friendly relations. This term is used by associative encountered to designate a non-sexual female partner, a sister, a confidant who accepts them as a goorjigeen with whom they have very good friendly relations. Just as the term gay friend is used to refer to a man who is not a goorjigeen but who accepts goorjigeen (interview with a president of a MSM association, Dakar, August 2010).

\section{Establish a relationship of trust with my informants}

In general, our discussions, but also "word of mouth" worked

${ }^{8}$ Symbolically, he designates in the MSM milieu, the one who "opens" to the other during sexual intercourse between men. It is usually designated by the qualifier of passive and socially is often confused with effeminate men. $\mathrm{He}$ is often referred to in public space as the goorjigeen [man-woman]. For more details read Gning N, 2013, "Une Réalité complexe. Sexualités entre hommes et prévention du sida au Sénégal, Bordeaux, thèse de Doctorat en Anthropologie de la sante, Université Victor Segalen de Bordeaux II. 
well, allowed me to establish a relationship of trust with my informants. The men were very attentive to the way I was behaving and interacting with them. The attitude I adopted was characterized by the suspension of judgment, whereas in daily interactions with NGOs (not MSM) these men reported forms of judgment (refusal to greet them, homophobic speeches, etc.), attention expressed in visiting them at home, answering some of their invitations, etc. This relationship of trust also manifested itself in solicitations for more personal problems. Thus, during my investigation, I was sometimes enlisted as mediator during certain disputes. It could not have been done without this sympathy, but more broadly without the confidence they have given me. Our relation was cordial and they never missed an opportunity to express me their attention, making for example visit when I was suffering. The quality of our relationship and their interest in my research also resulted in my introduction through them to people who might be interesting for the study (non-associative, minors, women with multiple sexual identities) without waiting for any financial motivation on my part, which was not the case at our first meetings.

\section{From institutional legitimacy to ethnographic encounter}

Initially, my institutional connection with ANRS through my funding gave me credit one both sides with local NGOs and associative MSM. Indeed, after waiting three months to get a response from the coordinator of the NGO (not MSM, invested in the fight against AIDS among men with multiple sexual identities in Senegal), it was enough that I mentioned in a final letter the funding of the ANRS so that my request for internship is immediately reconsidered. I can also relate the confidence with which Leon (secretary-general of an association of MSM) had received me by handing me a key ring with the abbreviation of ANRS: "we trust the donors who finance us. ANRS we know them very well we have already had to work with some researchers. In addition, the fact that it is ENDA that put us in contact is a pledge of confidence". Yet very quickly, it seemed imperative to observe another posture. Indeed, during the investigation, two men did not show up for the appointments. I tried to understand the reasons for these refusals. It was then, as I approached a member of an association, that he related to me the rumors which circulated about my account: "She is too much of a root. She reimburses little while she works for the ANRS and the local partner". This is important because it could be a constraint to access my informants. Indeed, an associative leader in another locality had warned me "Gnagna, avoids that the MSM give you bad publicity, because the rumors circulate very quickly in the MSM environment". As I mentioned above, "word of mouth" is a communication technique widely used in MSM community. This experience led me to undertake new approaches with some associations to better clarify my position on the field. My work was perceived in the light of other investigations conducted with them and involving the payment of large sums of money to informants. The example of an ongoing investigation was given to me and for which the facilitators explained receiving 150,000 FCFA (260.60 $\$$ US). Similarly, during the seminars organized by the local NGOs (in which I participated), the reimbursement of transport costs exceeds 50,000 FCFA (86.87 \$US). Compared to these amounts, the 2,000 CFA francs (3.47\$ US) that I intended for transport costs seem derisory. These disappointments prompted me to question the hyper-solicitation of my informants since the arrest of the nine associative in 2008 and to incorporate this reflection into my dissertation.

${ }^{9}$ Amount can change regarding the exchange rate.
Victim status became a source of income by the remuneration of testimony, according to a logic described in Ivory Coast and Burkina Faso by Vinh Kim Nguyen. ${ }^{24}$ On this basis, I had to build my identity as a researcher to use the expression of Daniel Bertaux. ${ }^{12}$ Marieke Blondet's ${ }^{19}$ experience in the field of American Samoa after the passage of Margaret Mead shows how the work of those who preceded us can be an obstacle to which the researcher is confronted despite himself. This is a legacy he must negotiate. The author explains ${ }^{19}$ that "the passage of Margaret Mead in American Samoa left a rather negative image of anthropology and somewhat discredited ethnologists, especially women". But it also highlights the fact that people already have some knowledge of what the researcher should be. In fact, their demands are often motivated by the performances are part of the city. In other words, for her, "from an indigenous point of view, regardless of gender, the ethnographer is often perceived as a source of wealth and prestige and as the representative of the colonial power" (ibid: 76). Certainly, as far as I am concerned about, the situation is different because I am not in total alterity because I am Senegalese. However, the interpretations of otherness are multiple: I am a woman, student in France and financed by ANRS. Moreover, the solicitations of investigations are not the only function of the status of foreigner or ethnologist. The experience of Blandine Bila, ${ }^{25}$ conducting a study in his hometown Ouagadougou, is a perfect illustration. She shows the applications to the researcher are not peculiar to the position of stranger who occupies it in the community studied. She points out that the Aboriginal researcher is as much as requested or even more so than his foreign colleague. She is specialized in research and development: ${ }^{25}$ "my autochthony, by favoring the prolongation of expectations of me beyond the term, distinguishes me from my expatriate colleague, the northern coordinator of the program, present by intermittence on the field and joining his country at the end of the program. Thus, neither the conditions of his relations with the participants nor the stakes of relations are not the same for him and for me ". And she explains by referring to her experience: "the researcher finds herself well placed, welcome in various social strategies (multiform expectations), not the lack of satisfaction in the future entails a risk of a change in friendly relations (fear of deterioration of the relationship)"(ibid: 5). Taught by the example of Blandine Bila, ${ }^{25}$ to avoid a negative rumor spreading on me among the MSM, I organized a new meeting with my informants to explain them how my research, which falls within the framework of my Doctorate, is different from other research they participated before. This time I also insisted on the state of the student insofar as for my informants, the ANRS being an international donor, the reimbursement of their transport costs seemed to them legitimate. Indeed, as Daniel Bertaux ${ }^{12}$ pointed out to the respondents "if you are a student, this is an advantage, they will want to help you. If you are the researcher it is that you are paid for this work: by whom? To do what? ". In addition, as a trainee, I was perceived as a member of this NGO, so seen differently. So, it became imperative to clarify my independence from local partner by specifying the reasons for the immersion. In view of this experience and in hindsight, I was certainly awkward when I introduced myself. Certainly, at the beginning, this allows me to be advantageous, more on my field we must constantly re-adapt; readjust according to the spaces and the interlocutors. Trust has also played a key role in this research. Indeed, if the status of student can generate sympathy, it is not enough all times to succeed in its immersion on the field. My work has not only been summarized in the interviews, but also in the accompaniment of individuals in their daily lives with informal discussions and so on. This created trust between me and my informants. In short, in a more decisive way, 
it is through privileged friendly relationships with some (associative leaders as well as MSM members) for whom there is no question of "paying a meeting, or time spent with them", that the investigation reports have evolved very significantly. Being suspicious at first, my interlocutors were more costly, cooperative, available and admiring to me. Thus, this relationship of trust established over time led them to discuss with their peers, stressing my position as a young researcher, courageous (according to their comments), independent of any NGO whom they can discuss without censorship and even discuss conflicts of interest with local partners, which they did not have the opportunity to do in the other researches because the stakes were different.

\section{Medical ethics in social sciences}

In his study on AIDS, Laurent Vidal ${ }^{26}$ points out: "As much as moral and intellectual and epistemological requisites, ethical arguments also represent justifications and assets for the anthropological approach". I already had experience with AIDS research and issues of confidentiality and anonymity (Gning, $2006 \& 2008$ ). But in this research, the question of ethics occupies a central place and arises with certain acuity. I am aware that the issue of homosexuality is a sensitive question in most African countries, including Senegal. The situation of visibility of these men since 2008 has provoked many controversies and a series of violence. Senegal is a country with 95 percent Muslim and homosexuality is subject to moral reprobation (largely due to religion and cultural values). I have reflected on how to keep my informants anonymous. The challenge is to make "hidden anthropology" from a discriminated and stigmatized sexual minority. The difficulty posed by this work consists in articulating presentation of data and protection of anonymity. As a result, confidentiality and anonymity were placed at the heart of the relationship with my respondents. Thus, for anonymization, I modified, with the agreement of my informants, some characteristics (name, surname, place of residence, profession, etc.) likely to have them identified. This explains the choice of pseudonyms in this article. In short, all interviews are anonymous. Recordings of the interviews were destroyed after transcription. At the same time, I pledged not to disclose the respondents' words to those around them. Nevertheless, despite the precautions taken to respect the confidentiality and anonymity rules of my informants, other difficulties have arisen. As Jean-Pierre Dozon ${ }^{27}$ notes: "the field is not self-evident or, rather, it can be overwhelming with misunderstandings, overloaded with actors or third parties to whom the ethnologist would have liked not having to confront, or simply become impracticable". In this research go through a local NGO (not MSM) was necessary to have a first contact with my informants. This is how I begin a six-month internship at NGO in March 2010. But as soon as I first met with the MSM association, I explained to them the confidentiality clauses of the study and I was questioned by the MSM manager at the NGO. He reminds me the moral commitment that binds me to the NGO. A moral commitment that requires a right control over my work. This situation expresses the fear of seeing the information gathered from the MSM used against the NGO (as initially pointed out to me by the NGO coordinator). It should be noted that if immersion in an NGO has facilitated access to informants, from an ethical point of view this requirement to access the respondents' comments is not without problems. In these circumstances, is it necessary to respect the confidentiality pact that binds me to my informants; or provide information about them and expose them more to the tensions that already exist between them and their local partner? Should everything be accounted for and how should it be accounted for? How to reconcile ethnographic approach, respect for confidentiality (in the environment in which the research was conducted), sharing of information and commitment to the NGO?

\section{Sharing information}

The restitution of survey data remains a very delicate operation in certain contexts and more particularly in an environment of inter-cognition, where it is difficult to respect the confidentiality of informants' comments. Revealingly, this is what Aude Beliard \& Jean-Sébastien Eideliman ${ }^{28}$ show in their study on the question of the daily care of dependent persons. Regarding this study, the authors consider that: "the respect of the private dimension of the respondent's person covers two very distinct questions. On the one hand, readers outside the survey may be able to recognize those who participated in the survey. On the other hand, they can recognize each other ". This situation invites authors to choose: "to reconstitute fictitious cases by mixing several parts of different cases or by modifying the structure, for example family, of a case, so that a person who recognizes himself / herself cannot systematically deduce that the other persons represented in the case are close relatives. Such an operation requires several divisions: first between the analysis (which is carried out on the real cases) and the exposure of the results (which consists of mixing cases without modifying the conclusions), then between the reader community the disposition of which must be kept a document specifying how the 'real' cases presented themselves how they were mixed to construct the cases set out in the text) "(ibid.: 138). Inspired by the approach of these authors, I chose to divide the various testimonies gathered to better anonymize my informants. I therefore decided to report only the problems identified without disclosing the identity of the persons concerned and to remain at a general level by addressing the question of family, work and participation, which respects confidentiality. This protects both my informants while respecting my commitments to NGOs. At the same time, certain ethical research committee requirements for the informed consent process have led me to develop an ethics that is better suited to my research. I propose to address it in this section below.

\section{The Ethics of my research}

Following the medical trials of the Nazi doctors in Nuremberg, the code of the same name was developed and adopted in 1947 to protect the participants in medical studies. This code also concerned experiments carried out on detainees (without their consent) in other countries such as the United States or Great Britain. One of the fundamental principles of this Code is informed consent, which must be a prerequisite for any research on human subjects. While this Code was only concerned with "medical experiments" at the beginning, since the ratification of the Helsinki Declaration in 1964 and its revision in 1975 in Tokyo, social science researchers working on health are subject to the same rules as the doctors. However, this rule is not applied in the same way in France, for example, as in the countries of the South. ${ }^{7}$ In the context of AIDS, ANRS has been a main actor in the development of ethical reflection. This funding agency requires researchers working in developing countries to go to an ethics committee for funding (see Ethical Charter on Research in Developing Countries). However, this does not mean that social scientists were unaware of ethics in their research, but as Didier Fassin ${ }^{5}$ remarks: "the ethos of the researcher founded the ethics of his research". This led me to file a form with the ethical research committee of Senegal before the beginning of my research. On May 31, 2010, I received an email from the committee. 
Here are some of his requirements. "The Committee in its session of May 12, 2010 examined the SEN 11/10 protocol entitled An Invisible Reality: Homosexuality and AIDS Prevention in Senega ${ }^{10}$ and noted the following comments:

a. The Committee finds the study interesting from the scientific point of view, but asks the sponsor to clarify the methodological aspect and to review the process of collecting consent.

b. The immediate destruction of records is not acceptable because of the need to go back to source to verify if statements were not cross-dressed.

c. What is the relevance of depositing the consents signed in France? It is better to secure the forms in Senegal and ensure that they are not accessible to anyone.

d. The consent form is an evidence of an agreement between researcher and respondent and help to clarify the responsibilities in case of dispute and if the name of the signer is disguised, this card is no longer valid ".

e. Upon receipt of the e-mail, I explain to the permanent secretary of the committee that these requirements are problematic. By deferring the exact names and surnames, the anonymity of the identity of my respondents is no longer respected, whereas for these men, respect of this one seems to be paramount to participate in this investigation.

The Permanent Secretary advises me to exclude anyone who refuses to comply with this rule. He also asks me not to involve minors in this study. As stated by Didier Fassin, 5 "medical ethics rests on three principles: informed consent, risks and benefits for respondents and selection of subjects, the application of these rules from the biomedical sciences to the social sciences is essentially the first aspect that is taken in consideration, insofar as the questions of 'risks and benefits' and 'subject selection' have less relevance ". I have experienced it on my own field. Indeed, if in its recommendations the committee asks me to prove that the speech was not disguised, that everyone signed the agreement, etc., never the question of the risks taken by my informants and my ability to adapt a research practice to context and survey situations does not appear. From this point of view, it seems here that medical ethics is above all a means of protecting the researcher. This situation led me to negotiate the normative ethics of doctors to develop a pragmatic ethic closer to real life (a situation which the ethnographic investigation tries to approach) taking into consideration my relationship with my informants, in other words, their expectations and respecting their fears. To summarize, in the first instance, with the will to respect the ethical prescriptions and to be able to begin the investigation, I corrected my file again taking into consideration the remarks of the committee (cited above). However, concretely on the field, this rule, which applies to informed consent, has not been respected for the following reasons. First, some MSM did not want to report directly on the form their exact names. So, I left them the opportunity to change their identity. Indeed, in many African societies, if the word has more symbolic value, the writing on the other hand is much feared. In this context, informed and dated consent entails a certain responsibility that the actors are not willing to accept because of the social representations on the written word and the context of homosexuality in Senegal. Therefore, following the recommendation of the committee would have led me to give up investigations. Secondly, in certain circumstances of interaction

${ }^{10} \mathrm{~A}$ provisional title. The final title of my thesis dissertation is "Une Réalité complexe. Sexualité (s) entre hommes et prevention du sida au Senegal” (meals, seminars, discussions, etc.) and in certain places (waiting room, hospital ward, nightclub, etc.) the signing of consent proved difficult, even unnecessary, insofar as this contradicts the principles of observation. The principle of observation (as described by Bronislaw Malinowski) implies that the researcher must be "forgotten" to informally collect certain data that escape interviews, in other words, information outside the formal framework of investigation. Thus, during meals, conferences and other meetings, I interviewed men with multiple sexual identities to whom I voluntarily decided not to sign anything because the framework was not appropriate. Finally, since the ethics committee asked me to involve only men over 18 old, having received the verbal consent of the minors I did not ask them to sign form. The field led me to meet them and rather than ignore them, to respect the form of ethics, I respected his spirit by meeting these young people (under the description of reality which is at the heart of the process Ethnographic), but by not signing them to protect them. This reflexive approach testifies, beyond a work on me carried out within the framework of my investigation, of the relationship of the Senegalese society to the homosexuality. In addition, I wanted to show that anthropological ethics emerge more from a permanent negotiation with the conditions of investigation in the respect of the other (with its expectations and fears) than with the application of a rule of interaction predefined and validated by a signature by which the respondent expresses in a definitive way his agreement to participate in the investigation. This allows me to discuss the difference between a formal ethic (embodied in the signing of a consent form) and a contextual ethic more adapted to the realities of the field and based on trust that is not translated into a signature, but in an attention, a respect and an act. The questions addressed for this research concern anthropological practice in general. They allowed me to fine-tune my methodology throughout the survey and while writing the data. ${ }^{29}$

\section{Acknowledgements}

None.

\section{Conflict of interest}

Author declares there is no conflict of interest.

\section{References}

1. Agier M. Ni trop près ni trop loin. De l'implication ethnographique à l'engagement intellectuel. Gradhiva. 1997;21:69-76.

2. Ghasarian CH. De l'ethnographie à l'anthropologie réflexive. Nouveaux terrains, nouvelles pratiques, nouveaux enjeux. Éditions Armand Colin, France; 2004. p. 248.

3. Leservoisier O. Terrains ethnographiques et hiérarchies sociales. Retour réflexif sur la situation d'enquête. France; 2005. p. 327.

4. Bouillon F, Fresia M, Tallio V. Terrains sensibles Expériences actuelles de 1'anthropologie. Le Bulletin Amades. 2005;68:208.

5. Fassin D, Bensa Al. Les politiques de l'enquête. Épreuves ethnographiques, la Découverte. France; 2008. p. 331.

6. Vidal L. Réfléchir l'objet: pour une rénovation des sciences sociales de la santé. Autrepart. 2004;(29):3-12.

7. Desclaux A. L'éthique médicale appliquée aux sciences humaines et sociales: pertinences, limites, enjeux et ajustements nécessaires. Bulletin de la Société de Pathologie exotique. 2008;101(2):77-84.

8. Becker H. Outsiders. In: Métailié AM, editors. Etudes de sociologie de la déviance. France; 1985. p. 247. 
9. Ouattara F. Une étrange familiarité. Les exigences de l'anthropologie 'chez soi'. Cahiers d'études africaines. 2004;175:635-657.

10. Durkheim E. Les règles de la méthode sociologique. Éditions Flammarion, France; 2010. p. 333.

11. Dozon JP, Fassin D. Raison épidémiologique et raisons d'État. Les enjeux sociopolitiques du Sida en Afrique. Sciences Sociales et Santé. 1989;7(1):21-36.

12. Bertaux D. L'enquête et ses méthodes. Le récit de vie, 2nd ed. Armand Colin, France; 2006. p. 126.

13. Gning NN. Analyse d'une controverse. Les discours sur l'homosexualité dans l'espace public au Sénégal. Stichproben. 2013a;13(24):93-120.

14. Pollak M. L'homosexualité masculine, ou le bonheur dans le ghetto? Communications. 1982;35(1):37-55

15. Diawara M. Les recherches en histoire orale menées par un autochtone ou l'inconvénient d'être du cru. Cahiers d'Études africaines. 1985;25(97):5-19.

16. Rhani Z. Le Saint et l'ethnologue: sur les voies de l'ethno-ascèse. Altérités. 2009;6(2):115-128.

17. Bourdieu P. Sur l'objectivation participante. Réponse à quelques objections. Actes de la recherche en sciences sociales. 1978;23:67-69.

18. Leservoisier O, Vidal L. L'Anthropologie face à Ses objets. Nouveaux contextes ethnographiques. Éditions les Archives contemporaines, France; 2007. p. 295

19. Blondet M. Le genre de l'anthropologie. Faire du terrain au féminin. In: Alban B, Didier F, editors. Les politiques de l'enquête, La Découverte, France; 2008. p. 59-80.

20. Broqua C. Enjeux des méthodes ethnographiques dans l'étude des sexualités entre homme. Journal des anthropologues. 2000;82-83:129-155.
21. Awondo P. Homosexualité, sida et constructions politiques. Ethnographie des trajectoires entre le Cameroun et la France. École des Hautes Études en sciences sociales, Thèse de doctorat, France; 2012.

22. Gora MBODJ. Corporéité et Socialisation en milieu Wolof: place et importance du corps et des pratiques corporelles dans la société Wolof. Traditions et Changements sociaux, Thèse de Doctorat, Université Toulouse 2, France; 1988.

23. Gning NN. Une Réalité complexe. Sexualités entre hommes et prévention du sida au Sénégal. Thèse de Doctorat en anthropologie sociale et culturelle. Université Bordeaux 2, France; 2013b.

24. Nguyen VK. The Republic of Therapy, Triage and Sovereignty in West Africa's Time of AIDS. Duke University Press; 2010. p. 256.

25. Bila B. Anthropologie 'chez soi' avec des personnes vivant avec le VIH à Ouagadougou: Empathie et méthode et position des acteurs. Revue en ligne des sciences humaines et sociales. 2008;17.

26. Vidal L. Méthode et éthique: l'anthropologie et la recherche confrontées au sida. In: Michel A, editor. Anthropologues en Dangers L'engagement sur le terrain. Editions Jean-Michel Place, France; 1997. p. 99-107.

27. Dozon JP, Bouillon F, Fresia M, et al. Terrains sensibles. Expériences actuelles de l'anthropologie, Éditions de l'EHESS-CEAF, France; 2005. p. 7-11.

28. Béliard A, Eideliman JS. Au-delà de la déontologie. Anonymat et confidentialité dans le travail ethnographique. In: Bensa A, Fassin D, editors. Les Politiques de l'enquête Épreuves ethnographiques, La Découverte, France; 2008;123-141.

29. Dozon JP, Vidal L. Les sciences sociales face au Sida. Cas africains autour de l'exemple ivoirien. Orstom. France; 1995. p. 300. 